\title{
Radostaw Rusnak
}

(iD) https://orcid.org/0000-0002-8669-5258

\section{NIE-OBECNY NOWY TESTAMENT. DO DYSKUSJI O KSZTAŁCIE WYZNANIOWYM POEZJI RELIGIJNEJ JANA KOCHANOWSKIEGO}

\section{SŁOWA KLUCZOWE}

Jan Kochanowski; poezja religijna; Nowy Testament; Treny; literatura polskiego renesansu

Nieco zaniedbanym zagadnieniem $\mathrm{w}$ ramach zdecydowanie nienowego, a ostatnio za sprawą Aliny Nowickiej-Jeżowej (Nowicka-Jeżowa 2015: 216-274) reaktywowanego, sporu o wyznaniową tożsamość autora Fraszek jest kwestia jego stosunku do tradycji staro- oraz nowotestamentalnej. Stosunek ten być może trochę nazbyt radykalnie, aczkolwiek w najogólniejszym zarysie dość trafnie scharakteryzował przed laty Aleksander Brückner, pisząc, iż czarnoleski twórca „motywy poetyckie czerpie wyłącznie ze Starego Testamentu [...], nigdy z Ewangelii” (Brückner 1924: 71). Drobiazgową egzemplifikację tej tezy przynosi, jedyne bodaj tak ukierunkowane, studium Wilhelma Fallka, Świat biblijny w twórczości Kochanowskiego (Fallek 1931). I tak, jeśliby pominąć najbardziej ewidentne przejawy posiłkowania się

Radosław Rusnak - dr hab., Uniwersytet Warszawski, Instytut Literatury Polskiej, ul. Krakowskie Przedmieście 26/28, 00-927 Warszawa; e-mail: rrusnak@uw.edu.pl

(C) by Łódzkie Towarzystwo Naukowe, Łódź, Poland. This article is an open access article distributed under the terms and conditions of the Creative Commons Attribution license CC-BY-NC-ND 4.0 (https://creativecommons.org/licenses/by-nc-nd/4.0/) 
przez Kochanowskiego tekstem natchnionym - a więc jego Zuzannę, Pieśń o potopie i, rzecz jasna, Psatterz Dawidów - znajdziemy w tej wiekowej już pracy, bardziej lub mniej przekonywające, odwołania do Ksiąg Hioba, Jeremiasza i Przysłów, jeśli idzie o wyobrażeniowe tło Hymnu, w przypadku Trenów do każdej z trzech wymienionych tu ksiąg, a prócz nich także do Eklezjastesa i Habakuka, w odniesieniu do Odprawy zaś - do Deuteronomium i proroctwa Micheasza. Wyraźnych nawiązań do Księgi Liczb dopatruje się ponadto badacz w Modlitwie o deszcz (fraszka III 72), konkretne zapożyczenia leksykalne z Izajasza wskazuje natomiast w tekście Proporca, we fraszce Do Jana (III 20) i niektórych pieśniach z Fragmentów. Wszystkie z kolei wspomniane utwory Mistrza Jana nosić mają, zdaniem Fallka, również silne stylistyczne piętno psalmów. Jeżeli idzie zaś o ewentualne „similia” czarnoleskiej poezji i określonych ksiąg Nowego Testamentu, nie odnotowuje on ani jednego takiego przypadku (Fallek 1931: 383-421) ${ }^{1}$.

Mniej lub bardziej ugruntowane w literackim materiale przekonania niegdysiejszych uczonych poddają się obecnie, łatwiejszej niż kiedykolwiek wcześniej, weryfikacji za sprawą dostępnych dziś słowników, gromadzących ogół użytych przez Kochanowskiego form wyrazowych (Kochanowski 2008b; Stownik polszczyzny Jana Kochanowskiego 1994-2012). To m.in. dzięki nim możemy być pewni tego, iż samym imieniem Chrystusa posłużył się autor Satyra w obrębie całej swej spuścizny jedynie dwukrotnie: raz w polsko-, raz w łacińskojęzycznej jej części.

Pierwszego z przykładów dostarczają Wróżki, gdzie ustami Plebana tak oto mówi się o religijnej motywacji wszczynanych przez człowieka wojen:

...wszystki wojny, którekolwiek jeszcze z przodku krześcijanie z pogany wiedli, znikąd nie pochodziły, jeno z rózności wiary; ani one krześcijańskie wojska albo własnej ćmy zebranych zakonników tak dalece o Jeruzalem albo o Konstantynopol z Turki i z Saraceny się bili, jako o samego Chrystusa więcej a o wiarę Jego (Kochanowski 1980: 684).

Dużo ciekawszy wszakże casus, znacznie wychodzący poza zwykłe przywołanie interesującego nas miana, stanowi - nieprzeznaczona przez autora do druku - łacińska elegia Osm., I 10. W niej to, po zaskakująco zaciekłej, jak na Kochanowskiego, krytyce obyczajów katolickiego kleru, zwraca się podmiot mówiący ku osobie papieża:

Sancte pater, si quid divum longinquus ab aris

Exaudire tubas inter et arma potes,

His te compellat verbis Petrus, optime pastor:

„Mi neque pro Christo fas capere arma fuit,

1 To samo zauważa: Graciotti 1989: 331-332. 
Tu vero, qui vis Petri successor haberi,

Quomodo pro regnis impia bella geris?”

(w. $45-50)^{2}$

Napomnienie, w sformułowanie którego angażuje się samego św. Piotra, nie pada, oczywiście, bez konkretnej, dość naglącej potrzeby. Powstanie utworu wiąże się mianowicie z drugim z pobytów Jana Kochanowskiego na Półwyspie Apenińskim (1556-1557), kiedy to Italia, udręczona przeciągającym się hiszpańsko-francuskim konfliktem, stanęła w obliczu jego kolejnej, wielce niepokojącej odsłony. Tym, który mimo określonych sygnałów wskazujących na bliski finał kilkudziesięcioletniego już zatargu wszelkimi siłami dążył do rozniecenia go na nowo, okazał się urzędujący ówcześnie papież Paweł IV (Gian Pietro Carafa). Owładnięty myślą o odzyskaniu z rąk Hiszpanów rodowych posiadłości Carafów w Kampanii wraz z Neapolem, nie zawahał się on podpisać zbrojnego porozumienia z Francuzami, a dla osłabienia spodziewanego kontrataku ze strony znienawidzonych przez siebie Habsburgów dążył do skierowania ku wybrzeżom Sycylii wojsk wrogiego chrześcijaństwu Sulejmana ${ }^{3}$.

Polityczne zapędy tego nadzwyczaj wojowniczego, nawet jak na standardy wieku XVI, „pontifexa” tak oto ujmuje w swej elegii polski poeta:

Impia commisit magnos in proelia reges

Foederaque invitis dissoluit superis.

Ipse per obstantes turmas stimulante Megaera

Efferus irato proelia miscet equo.

Quaque modo aeternis mactata est victima divis,

Heu dolor, humano sanguine dextra calet,

Sanguine dextra calet, mentem furiosa cupido

Exstimulat regni, Parthenopaea, tui.

(w. 37-44)

2 „Ojcze święty, jeśli cokolwiek boskiego możesz usłyszeć z daleka od ołtarzy, między wojskami i trąbami wojennymi, tymi to słowami do Ciebie, najlepszego pasterza, przemawia Piotr: "Nie godziło się, bym ja nawet dla Chrystusa sięgnął po broń, Ty natomiast, który chcesz być uważanym za następcę Piotrowego, dlaczego prowadzisz bezbożne wojny dla (ziemskich) królestw?«” (tłum. Ł. Berger). Cyt. z tekstu łacińskiego za: Kochanowski 2008a: 109, 111.

3 Z nowszych opracowań pontyfikatu Pawła IV zob. Dopierała 2019: 738-742.

4 „Wysłał wielkich królów na bezbożne wojny i rozerwał przymierza wbrew woli Niebian. Sam, podżegany przez Megerę, pośród zastępów wojsk wmieszał się w bitwę, niesiony przez rozszalałego konia. Gdzieby nie była składana bogom ofiara - o wielki bólu! - z prawej strony czuć ciepłą ludzką krew, bije ciepłem od krwi, rozszalała żądza posiadania Twojego królestwa, Partenope, pobudza jego myśli” (tłum. Ł. Berger). Cyt. z tekstu łacińskiego za: Kochanowski 2008a: 109. 
Emocjonalna reakcja Kochanowskiego na działania Carafy w równym stopniu co świadomością realnego zagrożenia nową wojną, jakie na przełomie 1556 i 1557 roku dało się odczuć w całej właściwie Italii (papieski sprzymierzeniec Henryk II planował wkroczenie na półwysep od strony, sprzymierzonej z Habsburgami, Sabaudii), motywowana była zapewne także ogólnie irenistycznym nastawieniem poety, który swego autorytatywnego patrona w tej kwestii znajdował przede wszystkim w Erazmie z Rotterdamus. By nie mnożyć tu przykładów antywojennych enuncjacji poety, ograniczmy się do wskazania tekstu mogącego uchodzić za swego rodzaju komentarz do sytuacji politycznej w Europie połowy lat pięćdziesiątych XVI wieku, a zarazem zdecydowaną ocenę jednej ze stron wzmiankowanej tu kampanii wojennej.

Mamy tu na myśli łacińską elegię II 11 ze zbioru Elegiarum libri quattuor (1584), w której męski bohater wiersza po dokonaniu definitywnego rozbratu z boginią Wenerą zwraca się do Karola V Habsburga, władcy Niemiec i Hiszpanii. Pochwała ustępującego właśnie z tronu monarchy, do którego osiągnięć zalicza Kochanowski m.in. zaprowadzenie ładu wewnątrz Rzeszy, ale i obronę chrześcijańskiej Europy przed zagrożeniem ze strony imperium osmańskiego brzmi następująco:

O pater, o rerum columen sublime cadentum,

$\mathrm{O}$ armis nunquam debilitate manus.

Tu priscam imperii maiestatemque, decusque

Consiliis poteras restituisse tuis.

Tu Rhenum et fractis domuisti cornibus Albim,

Cum supra ripas iret uterque suas.

Idem veliferas duxti trans aequora classes,

Et posuisti Afro clara trophaea solo.

Ultraque Herculeas findens vada salsa columnas,

Iunxisti imperio regna remota tuo.

Tu bello invictus, tu clemens hostibus ipsis,

Non Gallus, non hoc Saxo negare potest.

(w. $71-82)^{6}$

5 W jakimś stopniu inspiracją dla antypapieskiego ekskursu z Osm., I 10 mógł być dialog Rotterdamczyka Niewpuszczenie Juliusza II do nieba (Iulius exclusus e coelis), w którym prócz bezpośredniej krytyki innego arcywojowniczego „pontifexa” doby renesansu zawarł uczony Holender dość bezwzględną ocenę przeżartej patologią Kurii Rzymskiej.

${ }^{6}$ „Ojcze! Wspaniała podporo dla wszystkich nieszczęść! Ręko niewypuszczająca nigdy broni! Ty potrafiłeś przywrócić swymi radami wcześniejszą wielkość i sławę państwa. Ty, złamawszy rogi, pokonałeś Ren i Elbę, gdy ze swojego koryta rzeki te wystąpiły. Ty przez ocean powiodłeś żaglonośne okręty i na afrykańskiej ziemi trofea sławy zatknąłeś. Ty, prując słone wody za słupami Herkulesa, oddalone królestwa z państwem swoim złączyłeś. Jesteś niezwyciężony w boju i łaskawy dla samych wrogów, czego 
Niech nas jednak nie zwiedzie owa „niewypuszczająca nigdy broni ręka” („armis nunquam debilitate manus") - prowadzone przez Habsburga z dużym wysiłkiem i przez wiele lat działania wojenne zaczynają skutkować w momencie, gdy powstaje cytowana elegia, realnie zarysowującym się na horyzoncie pokojem, i to w skali, by tak rzec, pankontynentalnej. W sposób najbardziej ewidentny urzeczywistni się on już niedługo, bo wiosną 1559 roku, podpisaniem w Cateau-Cambrésis traktatu kończącego okres tzw. wojen włoskich: francusko-habsburskiego porozumienia, na przeszkodzie którego w ostatniej chwili stanęły właśnie niespełnione ambicje Carafy. W nie mniejszym wszakże stopniu niż na gruncie polityki zagranicznej tej „pacyfikatorskiej” aktywności ustępującego monarchy dane było również zamanifestować się w stosunku do jego niemieckich poddanych. Mamy tu na uwadze nade wszystko ustanawiający wolność religijną na terenie Rzeszy pokój augsburski z roku 1555 roku - jedno z donioślejszych osiągnięć władcy, znanego zresztą od początku swego panowania z relatywnie dużej tolerancji względem protestantów. I choć brak w elegii II 11 bezpośrednich odniesień do tego akurat dokumentu (sympatię Kochanowskiego dla idei tolerancji religijnej wydedukować można raczej z innych jego, irenistycznych z ducha, wypowiedzi ${ }^{7}$ ), nie da się wykluczyć, że i jego

ani Francuz, ani Niemiec nie może zaprzeczyć”. Cyt. z tekstu łacińskiego oraz jego polskie tłumaczenie za: Ioannes Cochanovius... 2008: 45-46.

Bardziej szczegółową analizę wymienionych w elegii II 11 osiągnięć Karola, jak również próbę powiązania wprowadzonego tym samym wątku politycznego ze znajdującą właśnie swój finał historią miłości do Lidii zob. w Rusnak 2019: 233-247.

${ }^{7}$ Szczególnej wagi kontekstem dla wspomnianej laudacji wydaje się końcowy ustęp elegii III 14, gdzie dokładnie w tej samej, co w wierszu II 11 konfiguracji wymienieni zostają Bachus, Herkules i Romulus. W pierwszym przypadku trójka antycznych herosów stać ma się rychło towarzyszami niebiańskiej chwały Habsburga. Otwartą kwestią pozostaje jednak, czy nagroda ta przysługiwać ma władcy za całokształt jego dokonań, czy też za którąś konkretną część jego aktywności. Gdyby wszak za instruktywne dopowiedzenie w tej mierze uznać drugi ze wspomnianych passusów, okazałoby się, że - zdaniem poety - na tego rodzaju uhonorowanie zasługują wyłącznie ci, którzy swe życie poświęcają idei powszechnego pokoju:

Quin ita vecordes trux dementavit Enyo,

Per diras caedes iri ut astra putent,

Sic Bacchum, sic Alcidem, fortemque Quirinum,

Magnorum titulus emeruisse deum.

Dignior at quanto dapibus Iovis ille fuisset,

Atque Hebes picto participare toro,

Qui bella exstinxet per terras omnia, quique

Pacem inter gentes inviolabilibus

Sanxisset pactis; huic aurea temple decebat,

Huic pingues tauros turaque odora dari. 
ogłoszenie wpłynęło na ostateczny kształt cytowanej tu apologii; tym bardziej, że nadzwyczaj zapiekłego przeciwnika porozumienie to znalazło w osobie Pawła IV ${ }^{8}$.

Jak wynika zatem z elegii II 11, odsłaniającej nieodzowny naszym zdaniem kontekst potępieńczej filipiki z utworu Osm., I 10, był Kochanowski w drugiej połowie lat pięćdziesiątych XVI stulecia zdeklarowanym zwolennikiem utrzymania tak politycznego, jak i religijnego pokoju w Europie, zbyt długo już borykającej się z burzliwymi konfliktami, także na tle wyznaniowym. Nic więc dziwnego, że na działania ówczesnego papieża, tak mocno godzące w kruchy, ledwie osiągnięty konsensus, poeta reaguje rzadko u niego odnotowywaną ,indignatio”, i że w efekcie pod adresem wojowniczego hierarchy pada tyle gorzkich uwag. Samo zresztą przywołanie pamiętnych wydarzeń z Ogrójca - i to ustami jednego z ich bezpośrednich uczestników, a zarazem niebiańskiego zwierzchnika Carafy, św. Piotra - stanowić ma argument w tę bezkompromisową antywojenną retorykę doskonale się wpisujący. Trudno bowiem wyobrazić sobie (teoretycznie przynajmniej) skuteczniejszy sposób na przemówienie do rozsądku zapalczywemu papieżowi, aniżeli odniesienie do jego osoby, odnotowanych przez ewangelistów, słów samego Chrystusa. Adekwatność obu skonfrontowanych ze sobą sytuacji, biblijnej i tej współczesnej autorowi, wzmacnia jeszcze analogia pomiędzy Szymonem Piotrem a jego żyjącym w dobie nowożytnej odpowiednikiem. Skoro aprobaty Syna Człowieczego nie zyskuje posłużenie się przemocą, gdy rzecz dotyczy nawet jego własnego bezpieczeństwa, tym bardziej na potępienie z jego strony zasługuje rozlew krwi wszczynany dla czysto ziemskich dóbr, w tym wypadku władzy (,pro regnis impia bella" [Osm., I 10, w. 50]).

Dodajmy, że z ambitnych planów wojennych Carafy niewiele wychodzi, a tak naprawdę kończą się one kompromitującą dla papieskiego autorytetu klęską. Dowodzący armią Filipa II we Włoszech książę Alba (właśc. Fernando Álvarez de Toledo) nie tylko bez większego trudu odzyskał utracone początkowo fortece, ale w toku błyskawicznej ofensywy zajął też dużą część Lacjum, by wreszcie zagrozić samemu Rzymowi. I jedynie należny głowie Kościoła respekt powstrzymał go przed definitywną rozprawą z przeciwnikiem. Po kilku miesiącach zmagań Hiszpanie

„Tak to szalonych ludzi otumaniła straszna Bellona, iż mniemają, że przez mordy okrutne do nieba można się dostać. Sądzą, że tylko tym sposobem Bachus, Herkules i dzielny Kwiryn na miano wielkich bogów sobie zasłużyli. Lecz o ile godniejszy uczt Jowisza i ozdobnego łoża Hebe byłby ten, który by wszystkie wojny stłumił na ziemi i pokój zaprowadził między narodami przez niewzruszone umowy. Temu należałoby wznosić złote świątynie i składać w ofierze liczne woły i wonne kadzidła”. Cyt. z tekstu łacińskiego oraz jego polskie tłumaczenie za: Ioannes Cochanovius... 2008: 66-67.

Por. poświęcony ostatnio tym kwestiom tekst: Dąbkowska-Kujko 2015: 238-253.

${ }^{8}$ Daleką od pobłażliwości czy woli dialogu politykę Pawła IV względem protestantyzmu prezentuje chociażby Ranke 1981: 246-271. 
wspaniałomyślnie przystali na powrót do „status quo”, a Paweł IV zmuszony został na dobre pogrzebać swe śmiałe polityczne cele?.

Przypomniana elegia, czy to z uwagi na swój zbyt antyklerykalny charakter, czy fakt zwykłego przebrzmienia oddanych w niej emocji, włączenia do zbioru Elegiarum libri quattuor (1584) ostatecznie się nie doczekuje. Pomija ją także Jan Januszowski, udostępniając drukiem niemal cały pozostający wcześniej w rękopisie dorobek Kochanowskiego, w tym utwory jawnie przez poetę nieukończone. W efekcie aż do wieku XIX, a więc do momentu publikacji tzw. Wydania pomnikowego, jedyną bezpośrednią wzmianką o Chrystusie, na jaką przeciętny czytelnik mógł się natknąć w dostępnej mu części czarnoleskiej spuścizny, była ta pomieszczona w tekście Wróżek.

I to wyczerpywałoby podniesioną przez nas kwestię, jeśliby tylko nie brać pod uwagę dwóch jeszcze przypadków, w których postać Syna Człowieczego przywołana zostaje nie wprost. W jednym z nim (mowa ponownie o Wróżkach) określony zostaje on jako „nawyszszy Prorok”, przywołuje się też w sposób bezpośredni jego, odnotowane przez Mateusza i Łukasza, słowa: „Omne... regnum in se divisum desolabitur” (Mt 12, 25; Łk 11, 17) (Kochanowski 1980: 684). Drugi casus stanowi, skierowane do Mariana Leżeńskiego, foricenium 9 (In imaginem Mariani), gdzie wzmianka o Jezusie, nazwanym zbawieniem rodzaju ludzkiego („salus”), służy przywołaniu Palestyny - celu podróży, w jaką planuje się udać adresat epigramu: „loca, ubi humano parta salus generi est” (w. 4: „do tych miejsc, z których dla rodu ludzkiego zbawienie wyszło"; Ioannes Cochanovius... 2008: 91) ${ }^{10}$.

To niemal bezwyjątkowe „oblivium” dotyczy zresztą nie tylko Syna Bożego, ale i innych ważnych postaci Nowego Testamentu. Prócz Piotra, nie wymienia Kochanowski żadnego z apostołów, brak u niego wzmianek o Samarytance, Nikodemie czy Marii Magdalenie, pomija zupełnie św. Pawła, prawie całkowitym milczeniem zbywa Maryję Pannę ${ }^{11}$. Raz, ustami Plebana z Wróżek, wspomina postać Poncjusza

${ }^{9}$ Najpełniejsze bodaj na gruncie polskojęzycznej literatury przedmiotu omówienie przebiegu kampanii neapolitańskiej lat 1556 i 1557 stanowi: Chłędowski 1959: 246-287.

${ }^{10}$ Gwoli porządku wspomnieć wypada i o informacji zawartej w akcie erygującym prepozyturę i mansjonarium w Krasnem koło Ciechanowa, Erectio Praepositurae et Mansionarium Krasne, jakoby Kochanowski był tłumaczem łacińskich „psalmów, hymnów i responsoriów o Męce Pańskiej” (Mańkowski, Skolimowska 1994: 95), których wykonywanie zaleca się we wspomnianym dokumencie. Dotychczasowe kwerendy nie potwierdziły istnienia tego typu utworów.

${ }^{11}$ Jedyny wyjątek stanowi tu fraszka Do dziewki (II 33), gdzie mowa o zwyczaju odmawiania modlitw codziennych:

Już tam służyć nie będą te pieszczone słowa:

„Stachniczku, duszo moja!” - Rychlej: „Bądź mi zdrowa,

Maryja, łaski pełna!"

(Kochanowski 1991a: 65). 
Piłata i pamiętny spór o Barabasza ${ }^{12}$. Także raz św. Jana Chrzciciela, patrona dnia, w którym święci się Sobótkę („na dzień świętego Jana / Zawżdy sobótka palana” - Panna 1, w. 11-12 [Kochanowski 1997: 91]). Podobnie po jednym razie przywołuje ewangelistę Marka oraz Łazarza, choć trudno orzec, by tak w pierwszym, jak i w drugim przypadku były to przywołania w pełni dla nich nobilitujące, zdradzają one raczej co najmniej sceptyczny stosunek poety do określonych elementów kultury chrześcijańskiej. W foricenium 17 (De spectaculis divi Marci) ulewa rozpraszająca uroczystą paradę skłania do powątpiewań w pozycję, jaką w niebiańskim panteonie zajmować przychodzi świętemu patronowi Wenecji. Z kolei fraszka $O$ Eazarzowych ksiegach (II 52), jeśli nie mylimy się co do jej zasadniczego rozumienia, mieści $\mathrm{w}$ sobie pytanie o wiarygodność wielce popularnego w wiekach średnich piśmiennictwa typu wizyjnego.

Mamy za to u Kochanowskiego kilka przynajmniej fraz mających dość solidne, jak się zdaje, zakorzenienie w tekście Nowego Testamentu. Należy do nich m.in. znana formuła z drugiego stasimonu Odprawy postów greckich, ujmująca przy pomocy metaforyki pasterskiej kwestię odpowiedzialności rządzących za los swych poddanych: „Wy, mówię, którym ludzi paść poruczono / I zwirzchności nad stadem Bożym zwierzono" (w. 163-164; Kochanowski 1962: 22). Pomimo licznych odwołań do tego samego typu obrazowania w księgach Starego Zakonu - czy to wówczas, gdy rzecz dotyczy wywodzącego się ze społecznych nizin Dawida, czy darzącego Izrael swą opieką Jahwe - prymarnego wzorca dostarcza tu jednak chyba figura ewangelicznego Dobrego Pasterza, i to do naśladowania jego ofiarnej dyspozycji względem powierzonych mu owiec zachęca się możnych słuchaczy monodiii ${ }^{13}$.

12 Stosowna wypowiedź bohatera dialogu brzmi następująco: „Nic w tym nie wątpię, żeby się wiele takich nalazło, co by na Piłata wołali: 'Dimitte nobis Barabbam”' (Kochanowski 1980: 687). Napomknąć wypada, że owo łacińskie przytoczenie stanowi przy okazji jeden z dwóch - obok przywołanego już wyżej - wiernych cytatów z Nowego Testamentu, jakie znaleźć da się w dorobku Mistrza Jana; pochodzi on zaś dokładnie z dwudziestego trzeciego rozdziału Ewangelii według św. Łukasza (Łk 23, 18), w wersji, jaką przechowała Hieronimowa Wulgata.

13 Zresztą rozstrzygnięcie kwestii, czy zastosowane tu obrazowanie ma swe źródło w Ewangelii, czy przykładowo, jak chcą tego autorzy Wydania sejmowego Pieśni (Kochanowski 1991b: 448), w ustanawiającej podobne co u Kochanowskiego relacje między Bogiem, władcą (Dawidem) a ludem Księdze Ezechiela (Ez 34, 23-24), miałoby kluczowe znaczenie dla ustalenia rzeczywistego zakresu, implikowanej w tekście, odpowiedzialności rządzących za swych poddanych. Gdyby bowiem, pisząc o „zwirzchności nad stadem Bożym”, autor Trenów miał na uwadze zawartą w Łk 15 przypowieść o zagubionej owcy, analizowany passus mieściłby w sobie imperatyw daleko posuniętej troski o życie każdego ze swych obywateli. A jeszcze radykalniej nakaz ów zdefiniować dałoby się w oparciu o Ewangelię według św. Jana, gdzie stwierdza się wprost: „Dobry pasterz daje życie za swe owce” (J 10, 11).

Niektórzy z wydawców Odprawy - np. Julian Krzyżanowski, ale i Tadeusz Ulewicz - wskazują dodatkowo na grecką, dokładniej zaś homerycką, proweniencję przywołanej metaforyki. Mają oni tu na myśli stosowane przez starożytnego epika sformułowanie „pasterz ludów”, peryfrastyczny 
Tren XIX skrywa ponadto parafrazę znanego z Łukaszowej Ewangelii $(Ł k$ 4, 23) wezwania do medyka (u Kochanowskiego: „Teraz, mistrzu, sam się lecz” ${ }^{\prime 14}$, w. 145), jak i wyraźne odwołanie do Rz 11, 33 („Skryte są Pańskie sądy”: w. 121). Fraza: „Duch - pry - gdzie chce, dmucha”" ${ }^{15}$, wreszcie z poematu Zgoda (w. 74) i pokrewny jej passus z Trenu XI (w. 7) uchodzą za nawiązanie do sławnego wersetu ze św. Jana $(J 3,8)$. Prócz tego parafrazę Chrystusowych słów o belce i źdźbłu w oku napotykamy w polemicznym wobec innowierców utworze $\mathrm{Na}$ heretyki (fraszka III 22): „Wyjmi, nieboże, bierzmo pierwej z oka swego, / A potym ździebłka sięgaj w oczach u drugiego" (w. 5-6) ${ }^{16}$. Wreszcie w wyraźnym nawiązaniu do innego Jezusowego pouczenia, o czekających potępieńców „płaczu i tesknicy” mówi się we fraszce Na posta papieskiego (I 50).

Ostatni z przywołanych przypadków zasługuje, być może, na słowo dodatkowego komentarza, ponieważ chyba niedostatecznie wyzyskano dotąd rzeczywiste konotacje użytego przez poetę ewangelicznego sformułowania.

Pośle papieski rzymskiego narodu,

Uczysz nas drogi, a sam chybiasz brodu.

Nawracaj lepiej niźli twój woźnica,

Strzeż nas tam zawieść, gdzie płacz i tesknica.

(w. 1-4)

- zwraca się poeta do (najprawdopodobniej) Luigiego Lippomana, nuncjusza apostolskiego w Polsce w latach 1555-1557, którego ofensywna, nielicząca się z rodzimymi realiami polityka antyinnowiercza nie tylko zwróciła przeciw niemu większość społeczeństwa szlacheckiego, ale i przesądziła o jego przedwczesnym wyjeździe z kraju ${ }^{17}$. Utwór Kochanowskiego oddawałby ogólną, panującą wówczas, opinię na temat niepopularnego dyplomaty, zarazem jednak mieściłby w sobie przytyk również do jego, wcale nie mniej kontrowersyjnego, mocodawcy, Pawła IV. I choć w jawnie negatywnym zdaniu na temat tego drugiego autor Fraszek miał szansę utwierdzić się rok później w trakcie pobytu we Włoszech - czego wyrazem

odpowiednik rzeczowników „król”, „władca”; mianem tym określony został choćby, ugodzony przez Deifoba, Hypsenor (Il., XIII 400). Skutecznie chyba jednak dezawuuje taką asocjację dalszy ciąg wywodu Kochanowskiego, gdzie mowa o „zasiadaniu miejsca Bożego na ziemi” (w. 166), nawet jeżeli za ich propozycją, teoretycznie, przemawiać mogłoby tematyczne powinowactwo poematu Homera i szesnastowiecznej polskiej tragedii (wszystkie polskojęzyczne cytaty z tekstu Pisma Świętego za: Pismo Święte... 1996).

14 Wszystkie przytoczenia z cyklu Trenów za: Kochanowski 1972.

15 Cyt. za: Kochanowski 1980: 51.

16 Wszystkie cytaty ze zbioru Fraszek za wydaniem: Kochanowski 1991a.

17 Najpełniejsze bodaj omówienie poselskiej aktywności Lippomana zawiera: Wojtyska 1977: $65-104$. 
wspomniana elegia Osm., I 10 - już w 1556 roku, przypuszczalnym czasie powstania epigramu, nad Wisłę dotrzeć musiały konkretne doniesienia o poczynaniach niedawno obranego papieża. Słyszeć mógł Kochanowski choćby o sprzeciwie Carafy wobec postanowień pokoju augsburskiego, mogły go dojść wieści o zamknięciu mieszkających w Rzymie żydów w getcie oraz obłożeniu ich innymi upokarzającymi obostrzeniami, czy też o podejmowanych niemal od momentu wstąpienia na tron Piotrowy przygotowaniach do wojny z Hiszpanią: w tym właśnie celu już w grudniu 1555 roku zawarł papież układ zaczepno-obronny z Henrykiem II, usiłował też nakłonić flotę sułtana tureckiego do ataków na wybrzeże Sycylii1 ${ }^{18}$.

Teoretycznie każdy właściwie z przywołanych tu powodów miał prawo wzbudzić w poecie wątpliwości co do kierunku, w jakim zdąża Kościół Chrystusowy jego czasów, a zauważmy, że wzięte z trzynastego rozdziału Ewangelii według św. Mateusza sformułowanie, przy pomocy którego ową ponurą perspektywę kreśli, wskazuje na piekło jako ostateczny punkt dojścia tak niefortunnie zarządzanej nawy Piotrowej. Nie ulega bowiem chyba wątpliwości, że „płacz i tesknica” odpowiada analogicznej w gruncie rzeczy parze: „fletus et stridor dentium” („płacz i zgrzytanie zębów"), jaka służy Jezusowi do wskazania, przewidzianego dla grzeszników, miejsca wiecznej kaźni (Mt 13, 42). Przestroga to nad wyraz poważna, upatrująca poniekąd we współczesnym autorowi „pontifexie” ulepionego wedle wyobrażeń innowierczej polemiki wyznaniowej Antychrysta, kogoś, kto przejął stery Kościoła jedynie po to, by sprowadzić na wszystkich wyznawców katolicyzmu potępienie. Sama omawiana fraszka stanowiłaby zaś, obok elegii Osm., I 10, jeden z wyraźniejszych przejawów antypapizmu Kochanowskiego - inna sprawa, że trudno jednoznacznie stwierdzić czy jakoś silniej w nim wówczas (tj. w połowie lat pięćdziesiątych XVI wieku) ugruntowanego, czy wynikłego raczej z doraźnej oceny poczynań Pawła IV tudzież ogólnej opinii szlachty jego czasów na temat wszędobylskiego Lippomana ${ }^{19}$.

18 Zob. Noel 2007: 283-284; Dopierała 2019: 739.

19 Nie sposób przy tym zgodzić się z Aliną Nowicką-Jeżową, która dla zneutralizowania antypapieskiego wydźwięku utworu zestawia go z innym wymierzonym w głowę Chrystusowego Kościoła epigramem, fraszką Na świętego ojca (I 44), tak jeden, jak i drugi wiersz uznając za przejaw niewykraczającego poza katolicką ortodoksję, a powszechnego w środowisku humanistycznym, antyklerykalizmu (Nowicka-Jeżowa 2015: 258). W istocie, podczas gdy fraszka I 44 dotyczy (ledwie!) kwestii mało moralnego prowadzenia się adresata („Świętym cię zwać nie mogę, Ojcem się nie wstydzę, / Kiedy, wielki kapłanie, syny twoje widzę" - w. 1-2), stanowi ponadto - jak chce tego Krzyżanowski (Kochanowski 1980: 772) - przekład, skierowanego do żyjącego sto lat wcześniej Pawła II, epigramu Jana z Panonii, poziom krytycyzmu w analizowanym przez nas utworze determinuje bezpośredni ogląd kondycji Kościoła, pobłażliwa zaś, w gruncie rzeczy, kąśliwość względem ludzkich słabości ustępuje w nim całkiem serio wyrażonej trosce o pośmiertny los katolików. 
Parę słów wreszcie dałoby się powiedzieć, choć to temat mniej ściśle już związany z samym Nowym Testamentem, i o szeroko pojętej tradycji chrześcijańskiej: historii Kościoła dawnych wieków, wyrosłej z teologicznej refleksji dogmatyce czy typowych dla wyznawców Chrystusa praktykach pobożnościowych, również w jakimś stopniu obecnych w pisarstwie Mistrza Jana. Wspomnijmy, w funkcji przykładu, o „świętych ojcach” z poematu Satyr, odpowiadających za wprowadzenie mitologicznego bohatera poematu w arkana nowej wiary. Odnotujmy, przywołany przez Kochanowskiego raz w kontekście humorystycznym (O prałacie, w. 15), raz wielce poważnym (Tren $X$, w. 11), czyściec tudzież sytuacje, w których napomyka on o mszy świętej ( $O$ drugim, w. 2), procesjach (Na heretyki, w. 3) czy sakramencie spowiedzi (Na nabożna, w. 2). Poeta wspomina wreszcie o niektórych z katolickich świętych: Mikołaju (Jezda do Moskwy, w. 382), Franciszku z Asyżu (Do starosty, w. 4) i biskupie Stanisławie, a właściwie o uzdrowionym przez niego Piotrowinie (Szachy, w. 382; Weintraub 1974: 6).

Ma ponadto w czarnoleskim dorobku swe niebagatelne miejsce - i na tym dość urokliwym „exemplum” poprzestańmy - indywidualna, praktykowana w gronie rodzinnym modlitwa. Wedle słów strapionego ojca, nigdy nie zdarzyło się małej Orszuli zaniedbać okazji, by codziennie powierzać swych rodziców Bogu (Tren XII, w. 11-14). Taka też, jak gdyby właśnie zajrzała o świcie do ojcowskiego pokoju, by wraz z nim klęknąć do modlitwy, jawi się ona bohaterowi Trenów wówczas, gdy dane mu jest ujrzeć ją ponownie w ramionach swej matki (Tren XIX, w. 7-10). Wspólnie odmawiany pacierz, a więc również wzięta z kart Ewangelii Modlitwa Pańska, okazuje się najczulej pielęgnowanym wspomnieniem bezpowrotnie minionej codzienności, samym jądrem utraconej czarnoleskiej sielanki ${ }^{20}$.

Nie mniej instruktywne od poszukiwań językowych czy wyobrażeniowych zależności czarnoleskiej spuścizny od ksiąg Nowego Testamentu byłoby wszakże wskazanie tych miejsc, w których interesujące nas odwołania wydawałyby się co najmniej pożądane, a czasem wręcz nieodzowne. Wiadomą kwestią, w świetle przedstawionych danych, jest zupełny brak zwrotów do Chrystusa, nie mówiąc już o jakichkolwiek wzmiankach o nim, w poezji religijnej Mistrza Jana. Syn Człowieczy nie występuje tam choćby w tradycyjnie przypisanej mu roli pośrednika

${ }^{20}$ Osobnym, zasługującym na dogłębniejsze opracowanie, problemem który wnieść może nieco i do podjętych przez nas rozważań, jest kwestia wyboru przez Kochanowskiego tych czy innych literackich autorytetów, zwłaszcza zaś gdy wybór ten dotyczy autorów podejmujących tematykę religijną. Najwyrazistszy bodaj przypadek stanowi tu Włoch Girolamo Vida, który rodzimemu twórcy dostarczył wzorca polskojęzycznych Szachów, lecz w nie mniejszym stopniu aniżeli swym, nawiązującym do tradycji greckiej, „heroicomicum” zasłynął wielce poczytną próbą eposu biblijnego, Christiadą (Christias, 1535). Leszek Teusz twierdzi wprawdzie, iż Kochanowski, prócz przełożenia Scacchia ludus, „pod wieloma względami inspirował się też duchem jego poezji w lirykach religijnych", ale tezy tej, niestety, nie egzemplifikuje (Teusz 2002: 243). 
zanoszonych do Boga błagań. Kochanowski prośby swe kieruje bezpośrednio do Stwórcy, nie tylko w obywających się bez tego typu mediacji psalmach Dawidowych, ale i reszcie dewocyjnej części swego dorobku poetyckiego. Człowiek doby renesansu, odczuwający silne, doświadczane na różne sposoby, powinowactwo z Najwyższym, nie potrzebuje, jak się zdaje, dodatkowo kogoś, kto łączyłby w sobie boską i ludzką naturę, a błagania swoje woli zanosić do bezpośredniego dyspozytora łask, o które zabiega. O ile podobna wybiórczość nie dziwi wówczas, gdy idzie o tak naturalną, dałoby się rzec, domenę Boga Ojca, jak władza nad żywiołami (Modlitwa o deszcz), o tyle trochę zaskakiwać może, przykładowo, brak jakiejkolwiek wzmianki o Chrystusie w utworze upamiętniającym jedną z kościelnych uroczystości z oktawy Bożego Narodzenia, jakim jest zredagowana na Nowe Lato, czyli dzień 1 stycznia, Kolęda.

Generalnie zresztą Bóg interesuje Kochanowskiego-poetę raczej jako odpowiadający za powstanie świata demiurg oraz gwarant trwania w nim niezakłóconego niczym ładu, także tego moralnego. Człowiek z kolei, widziany przez pryzmat czarnoleskiej twórczości, to przede wszystkim wyróżniona spośród innych Bożych dzieł istota, pewna swej uprzywilejowanej pozycji w hierarchii bytów, silnie zakorzeniona w harmonijnie uporządkowanym świecie, jaki dany został jej na mieszkanie, obficie korzystająca z łaskawości swego Kreatora. Niekoniecznie zaś postrzegać zwykł się on przez pryzmat własnej skażonej natury, a zatem jako ktoś, kto w pierwszym rzędzie potrzebowałby odkupienia za swe grzechy. W dużym stopniu poza tym język modlitewnych wypowiedzi Mistrza Jana - co pokazały wyliczenia Fallka - kształtuje wzorzec starotestamentalnych psalmów, a widoczne jest to już od pierwszego polskojęzycznego tekstu o tym charakterze, a więc pieśni Czego chcesz od nas, Panie...

Wszakże przynajmniej w jednym miejscu literackiej spuścizny Kochanowskiego moglibyśmy się spodziewać, drobnego choćby, odstąpienia od tej bezwyjątkowej, jak się okazuje, reguły, w miejscu - zaznaczmy - w którym rozkruszają się ideowe aksjomaty, jakim poeta dotąd bezwzględnie zawierzał, a wcześniej sprawdzające się mniemania, skonfrontowane z tzw. prozą życia, zaczynają ujawniać swą bezużyteczność. Mowa tu, oczywiście, o cyklu Trenów, które z ewangeliczną postacią Syna Człowieczego łączyć winien ponadto temat niezawinionego niczym bólu. Tymczasem, wbrew oczekiwaniom, w żadnym z dziewiętnastu tekstów zbioru nie napotykamy choć zdawkowej wzmianki o Jezusie i złożonej przezeń ofierze. W jego, wykrzyczanym z krzyża, „Boże mój, Boże mój, czemuś Mnie opuścił?” (Mt 27, 46; Mk 15, 34) nie znajdują odzewu równie rozpaczliwe wyrzekania ojca Orszuli, mierzącego się z podobnym duchowym zamętem („Nieznajomy wróg jakiś miesza ludzkie rzeczy" [Tren XI, w. 5]). A bezsens śmierci dziecka skutecznie przesłania jakąkolwiek perspektywę odkupieńczej mocy przeżywanego cierpienia. 
Skonstatowawszy rozpad aksjologicznych podstaw swego świata, bohater zbioru pogrąża się w coraz dotkliwiej odczuwanym bólu, nie jest to jednak ból, który wyprowadzałby go gdziekolwiek dalej, poza szczelny krąg własnych fantazmatów i obsesji, czy przynosił coś więcej poza skrajnym wycieńczeniem emocjonalnym. Świadczą o tym mitologiczne archetypy, których się chwyta, by w bezpiecznej dla siebie przestrzeni kultury stanąć oko w oko z własnymi przeżyciami. Przywołanie w Trenie XIV historii Orfeusza, samej w sobie naznaczonej refleksją o chimeryczności ludzkich starań, miast nadzieją na przebłaganie okrutnego losu („Gdzie by też tak kamienne ten Bóg serce nosił, / Żeby tam smutny człowiek już nic nie uprosił!” - w. 15-16) skutkuje rojeniami o dołączeniu do córki w mrokach Podziemia („Więc tamże już za jedną drogą / Zostać, a z duszą za raz zewlec troskę srogą" - w. 17-18). Niobe z kolei, bohaterka Trenu $X V$, to już zupełnie figura nieutulonego płaczu, gorzka zapowiedź tego, że łzy zrozpaczonego ojca płynąć mogą już wiecznie, ale też bezproduktywnie, bez cienia szansy na odmianę smutnego stanu rzeczy.

Dość odległy od Chrystusa okazuje się też Hiob, którego swoistym alter ego staje się podmiot Trenu XVII. I choć imię tego starotestamentalnego męża w utworze nie pada, jego postać dostatecznie mocno rzutuje na pomieszczoną w wierszu wypowiedź, a to za sprawą wyróżnionej inicjalną pozycją skargi: „Pańska ręka mię dotknęła” (w. 1), stanowiącej wierny cytat z Hi 19, 12 („manus Domini tetigit me”). W pozostałej zaś części wiersza Hiobowe w tonie narzekania krzyżować się będą z frazami wziętymi z Księgi Psalmów Dawidowych i komunałami stoicko ukierunkowanej dydaktyki ${ }^{21}$. Dla wyrażanych przez bohatera cierpień nie otwiera się w efekcie żadna odkupieńcza perspektywa, jaką niosłoby skojarzenie ich z ofiarą Chrystusa. W dość wąskim, zakreślonym przez starotestamentalny tekst, horyzoncie z pokorą przeżywany ból może co najwyżej służyć przebłaganiu surowego bóstwa i przybliżeniu szczęśliwej odmiany losu, gdy uzna ono, iż dopełniła się już miara nędzy „oranta”. Na to też zdaje się liczyć podmiot przede wszystkim Trenu XVII, ale i Trenu XVIII, w którym potrzeba uniżenia się przed Najwyższym wiedzie zbolałego ojca ku swoistemu zatopieniu się we wspólnocie wierzących, przyjęciu postawy grzesznego Bożego dziecięcia („My, nieposłuszne, Panie, dzieci Twoje” - w. 1), jakże odległej od świeżo przezeń porzuconej pozy mędrca i nauczyciela moralności. U kresu duchowo-intelektualnych zmagań bohatera cyklu dużo atrakcyjniejsza od poszukiwań „braterskiej”, by tak rzec, bliskości z umęczonym na krzyżu Bogiem-człowiekiem staje się więc rola wyczekującego na ojcowskie zmiłowanie syna.

${ }^{21}$ Zob. komentarze do Trenu XVII w: Kochanowski 1983: 162-164. 
Jak się zatem okazuje, sublimująca moc cierpienia nie wchodzi w zakres branych przez ojca Orszuli pod uwagę autokonsolacyjnych strategii - choć sama ta idea nie jest Kochanowskiemu obca, jako że zdarza mu się po nią sięgnąć, tyle że czerpiąc ją nie z kart Ewangelii, a z pism Horacego. Rzecz dotyczy dość analogicznej sytuacji, w jakiej znalazł się bohater jego łacińskich elegii pod koniec wielce wyniszczającego emocjonalnie związku z Lidią. Mierząc się z nieco podobną co w wypadku Trenów stratą i coraz silniej dominującymi jego postrzeganie rzeczywistości obsesjami, męski protagonista Elegiarum ima się coraz to nowych, na dłuższą metę jednak równie nieprzydatnych, środków zaradczych, tak by przy ich użyciu złagodzić ból odrzucenia i odzyskać elementarną choćby zdolność funkcjonowania ${ }^{22}$. Gdy nieskuteczne okazuje się i hedonistyczne korzystanie z darów Bachusa, i korne znoszenie (za radą Wenery zreszta) aplikowanych mu przez dziewczynę upokorzeń, coraz wyraźniej też elegijny bohater traci panowanie nad sobą, jako jedyna godna rozważenia jawić mu się zaczyna własna, zadana samemu sobie, śmierć. Aby uchronić się wszakże przed poczuciem zupełnej życiowej przegranej - kwestia ta staje się tematem elegii I 10 - projektuje on dla siebie miejsce w swoistym raju samobójców, pośród takich nieszczęśliwych kochanków, zarazem zaś wysokiej próby poetów, jak Orfeusz, Lukrecjusz i Safona ${ }^{23}$. Ów akt wyczekiwanej przez siebie sprawiedliwości, w którym podmiot wiersza pragnie widzieć publicznie zamanifestowany przejaw bożej interwencji, zapowiada takimi oto, kończącymi utwór, słowy:

Per purum quoties deus aethera praepete curru

Intonuitque vehens admonuitque sui.

Ille domat magnis confisum viribus, ille

Adflictum terrae lucida ad astra vehit.

(w. $77-80)^{24}$

Nie mogąc przejść obojętnie obok doznanego przez bohatera upadku, Jowisz, najskuteczniejszy gwarant moralnego ładu w świecie, w wyniku nagłej kratofanii ma wybawić go z nędzy i umieścić pośród uwielbionych. I choć idea tak radykalnego w środkach egzekwowania Bożej sprawiedliwości nieobca jest przecież tradycji

${ }^{22}$ Analogiczność sytuacji, w jakiej znaleźli się bohaterowie Elegarum libri quattuor oraz Trenów, każe doszukiwać się podobieństw również w podejmowanych przez nich próbach zaradzenia przeżywanemu kryzysowi. I jak się okazuje, zbieżności tych jest całkiem niemało. Zob. więcej: Rusnak 2019: $185-233$.

${ }^{23}$ O osobliwości owego wykoncypowanego przez poetę konstruktu zob. Urban-Godziek 2012: 15-35; 2014: 211-228; Rusnak 2019: 208-218.

24 „ilekroć bóg przemknie na szybkim rydwanie po czystym niebie i zagrzmi, aby dać znać o sobie, to zawsze poskromi on człowieka zbyt ufającego w swe siły, a leżącego na ziemi do jasnych gwiazd poniesie”. Cyt. z tekstu łacińskiego oraz jego polskie tłumaczenie za: Ioannes Cochanovius... 2008: 43. 
biblijnej - i to zarówno w wydaniu staro-, jak i nowotestamentalnym ${ }^{25}$ - rzeczywistym źródłem wykorzystanego tu konceptu okazuje się oda I 34 Horacego. W niej to gwałtowne uderzenie pioruna wyrywa podmiot mówiący wiersza, zdeklarowanego niedowiarka, $\mathrm{z}$ religijnego indyferentyzmu, napełniając go w równym stopniu metafizycznym lękiem, co i przekonaniem o aktywnym udziale Jowisza w biegu ziemskich wypadków. Wyraz temu prowidencjalistycznemu podejściu daje on zwłaszcza w finalnej, czwartej strofie utworu:

mutare et insignem attenuat deus

obscura promens: hinc apicem rapax

Fortuna cum stridore acuto sustulit, hic posuisse Gaudet.

(w. 13-16) $)^{26}$

Ignorując zatem takie choćby, zanotowane przez Mateusza, Chrystusowe pouczenie, jak: „Kto się wywyższa, będzie poniżony, a kto się poniża, będzie wywyższony" (Mt 23, 12), sięga podmiot mówiący elegii, sam osiągnąwszy swoiste „extremum” życiowej udręki, po tekst szacownego, a ponadto niewątpliwie bliskiego poecie, klasyka ${ }^{27}$. Przy czym - co warte odnotowania - w wykorzystanej tu odzie zasada, o jakiej mowa, w żadnym razie nie została przedstawiona jako generalne prawidło, wedle którego postępować ma czuwające nad ogólnym ładem bóstwo; inaczej więc, aniżeli w przywołanym tu tekście Ewangelii. A owo „wielkich poniżanie" $\mathrm{i}$ „małych podnoszenie” skorelowane jest przede wszystkim z działaniem bogini Fortuny, jako ledwie jeden z przejawów przysługujących jej prerogatyw.

W Trenach, jak zostało już powiedziane, chrześcijańskie rozumienie cierpienia jako czegoś obdarzonego wyjątkową mocą sublimującą, która zakorzenienie swoje ma w krzyżu, nie występuje i pomimo fizyczno-intelektualnych katuszy, jakie przeżywa ojciec Orszuli, to nie one przesądzają o uzyskanym przez niego ostatecznie zlitowaniu. W sposób dostateczny sugerują to końcowe stwierdzenia z Trenu XVIII, wyrażające tak rozmiar występków, które ciążą sumieniu „oranta”, jak i jego wiarę w nieskończone Boże miłosierdzie. To właśnie po finalnym: „Użyj dziś, Panie, nade mną litości!" (w. 28), nachodzi bohatera tajemniczy omam, stanowiący adekwatną - jak się zdaje - odpowiedź na wznoszone przezeń korne prośby.

${ }^{25}$ Zob. Rusnak 2019: 210.

26 „Bóg mocowładny wielkich poniża, / małych podnosi - losu igrzysko: / jeden po koronę sięgnął, / a drugi upadł nisko". Cytat z tekstu łacińskiego oraz jego polskie tłumaczenie za: Horacjusz Flakkus 1986: $142-143$.

27 Posłużenie się przez Kochanowskiego utworem Horacego, nie zaś - bardziej może oczywistym w tym kontekście - tekstem biblijnym, w jakimś stopniu daje się, rzecz jasna, tłumaczyć generalną preferencją udzielaną w zbiorze Elegii ksiag czworo autorom pogańskiego, grecko-rzymskiego antyku. 
Słowa komentarza domagałaby się jeszcze nakreślona słowami babki Orszuli rzeczywistość rajska. To, co w jej obrazie uderzające, to nie tyle nawet fakt zupełnego nieposiłkowania się przez poetę takimi fundamentalnymi dla żywych w jego czasach wyobrażeń nieba tekstami, jak Apokalipsa św. Jana czy jakże bogata literatura wizyjna (łatwo zresztą posądzić Kochanowskiego, choćby w świetle fraszki II 52, o generalną niechęć do późnoantycznej i średniowiecznej tradycji w tym względzie), a towarzysząca owemu wyobrażeniowemu ubóstwu tendencja do ujmowania raju raczej w kategoriach bliskich starożytnym epikurejczykom czy stoikom. Czyż nie tak bowiem rozumieć wypada sposób opisywania przez babkę Orszuli tej wielce pożądanej rzeczywistości raczej przy pomocy tego, czego w niebie nie ma, aniżeli tego, co w nim jest? Szczęśliwość, zaznawana przez obie zjawiające się strapionemu ojcu bohaterki, prócz osiągnięcia przez nie nieśmiertelności, oglądania Boga twarzą w twarz oraz bliżej niesprecyzowanych „szczerych rozkoszy” (Tren XIX, w. 65), polega bowiem głównie na niedoświadczaniu więcej tego, co przykre i bolesne, a nierozerwalnie spojone z doczesnością:

W niebie szczere rozkoszy, a do tego wieczne,

Od wszelakiej przekazy wolne i bezpieczne.

Tu troski nie panują, tu pracej nie znają,

Tu nieszczęście, tu miejsca przygody nie mają,

Tu choroby nie najdzie, tu nie masz starości,

Tu śmierć łzami karmiona nie ma już wolności.

(Tren XIX, w. 65-70)

Z kolei za swoistą realizację pragnień wyrażonych przez poetę choćby we fraszce $O \dot{z} y$ wocie ludzkim (I 101) wypada uznać obietnicę przekroczenia, często konstatowanej przez Kochanowskiego, bariery ułomnego ludzkiego poznania. „Wiecznej używamy / Dobrej myśli, przyczyny wszystkich rzeczy znamy" (Tren XIX, w. 71-72) - słyszy on z ust swej rodzicielki.

Kreślony w Trenie XIX raj nie tylko wydaje się zatem generalnie wyzbyty wyobrażeniowej chrześcijańskiej specyfiki, ale jego kształt w znacznym stopniu determinowany jest bliską poecie tradycją filozoficzną, wskutek czego reprezentuje w jakimś sensie punkt dojścia prowadzonych przez niego, w duchu epikurejsko-stoickim, poszukiwań niczym niemąconego szczęścia. Chrześcijaństwo dostarcza Kochanowskiemu jedynie ogólnie zarysowanego konceptu, który następnie wypełnia on bliską sobie treścią. Trwale skażona rodzinną tragedią doczesność nie wydaje się więcej przestrzenią, w której dałoby się zaznać owego pożądanego stanu. Konieczne zatem wydaje się przetransponowanie żywionych przez poetę aspiracji w realia mamiące obietnicą całkowitego odseparowania od nędzy żywota, takie w dodatku, które umożliwią mu połączenie się z opłakiwaną córką. Znaczące zresztą, że choć 
to właśnie dzięki śmierci i zmartwychwstaniu Chrystusa perspektywa zbawienia stała się dlań dostępna, postaci Syna Człowieczego znów w żaden sposób nie decyduje się on w ostatnim ze swych trenów odnotować ${ }^{28}$.

Czy poczynione tu obserwacje mogą wnieść coś istotnego do wciąż niezakończonego sporu o konfesyjny kształt twórczości Jana z Czarnolasu? Sama, kluczowa dla naszych rozważań, kwestia korzystania przez Kochanowskiego z tradycji nowotestamentalnej - ujęta w wymiarze zarówno całkiem literalnym, jak i bardziej ogólnym - jest w stanie dostarczać określonych argumentów tej czy owej stronie sporu chyba w dość ograniczonym, mimo wszystko, zakresie. Wnioski zaś, jakie zdawałyby się sugerować odnotowane tu dysproporcje, uznać wypada, po bliższym przyjrzeniu się sprawie, za nader wątpliwe. Nie jest bowiem tak, że zdecydowana preferencja dawana czy to Staremu, czy to Nowemu Testamentowi, pozwala w sposób ścisły przypisać danego autora do obozu bądź katolików, bądź innowierców. Z jednej strony wszak protestantyzm i typowe dlań przywiązanie do Pisma, odkrywanego w toku indywidualnej, pozbawionej mediacji lektury, dowartościowuje niewątpliwie księgi Starego Zakonu, otwierając swą epokę na nieco zaniedbywane dotąd kulturowe bogactwo judaizmu. Tym m.in. tłumaczyć da się karierę, jaką w piśmiennictwie doby renesansu zrobiły postaci patriarchy Józefa czy Zuzanny - traktowane zresztą częściej w kategoriach uniwersalnych, w gruncie rzeczy, wzorców prawego życia, nie zaś koniecznie umocowane w konkretnej tradycji religijnej i podległe w związku z tym uformowanym w oparciu o określone Boże nakazy normom moralnym. Taka też wydaje się, nieco wyabstrahowana ze swego macierzystego kulturowego kontekstu, słynna Joachimowa żona z młodzieńczego poematu Kochanowskiego. $Z$ drugiej zaś strony, tak jak trudno poetę parafrazującego trzynasty rozdział Księgi Daniela automatycznie przypisać z tego powodu do obozu reformackiego, tak ze wszech miar wątpliwą przesłanką po temu jest niemal uporczywe, jak mieliśmy się okazję przekonać, przemilczanie przezeń postaci Jezusa czy innych bohaterów ksiąg Nowego Testamentu. Zważywszy zresztą na

${ }^{28}$ Dodać wypada, że podobnie wyzbyte cech tradycyjnie chrześcijańskich są też te wyobrażenia nieba, które kreśli poeta jeszcze bez intencji radykalnego przeciwstawienia sobie obu rzeczywistości. A bardziej autorytatywnym dla niego źródłem inspiracji od tradycji biblijnej okazuje się Somnium Scipionis Cycerona. To właśnie ukształtowany wedle wyobrażeń Arpinaty raj ma na myśli Kochanowski, projektując wieczystą nagrodę dla wiernego sługi Rzeczypospolitej w pieśni II 12, to wreszcie do Cycerońskiej społeczności uwielbionych dołączyć mają cesarz Karol V z elegii II 11 czy Jan Amor Tarnowski z elegii IV 2, ale i z tekstu $O$ śmierci Jana Tarnowskiego.

Dodajmy, gwoli ścisłości, że raz jeden czarnoleski poeta posługuje się jawnie chrześcijańskim obrazem wstawania z grobów. Mowa tu o łacińskim foricenium 109 (Na Homera), gdzie w kontekście wiecznej sławy znamienitego greckiego epika padają słowa: „Mortuaque e tumulis in dias luminis oras” („Wstaną zmarli, rzuciwszy swe mogilne łoże”). Cyt. z tekstu łacińskiego za: Kochanowski 2008a: 705; polskie tłumaczenie za: Kochanowski 1986: 183. 
powszechnie znany chrystocentryzm nauk Lutra czy Kalwina, bardziej uzasadnione byłoby właściwie postrzeganie tej konkretnej specyfiki czarnoleskiego pisarstwa raczej jako znaku przywiązania do katolicyzmu.

Wydaje się jednak, że odpowiedzi na pytanie o przyczyny odnotowanej tu osobliwości szukać należy poza binarnie umiejscowionymi kategoriami konfesyjnymi. Mogło być bowiem tak, iż unikanie przez Kochanowskiego wzmianek o Synu Człowieczym wynikało z prostej obawy przed jakimkolwiek angażowaniem się w targające ówczesną Rzeczpospolitą spory dogmatyczne, których zasadniczym przedmiotem pozostawała właśnie osoba Chrystusa ${ }^{29}$. Ponadto, wyraźnie przyznawany tradycji starotestamentalnej prymat wiązać mógł się w większej mierze z dominantami intelektualnej formacji autora Fraszek, dzielonej zresztą z całym szeregiem wybitnych humanistów jego czasów. Wydaje się bowiem, że - niezależnie od faktycznego przesycenia jego pisarskiego dorobku myślą platońską - nad podzielanymi przez Kochanowskiego wyobrażeniami na temat Boga mocno ciąży filozoficzne dziedzictwo Akademii Platońskiej, upatrujące w Najwyższym przede wszystkim źródło takich szczególnej wagi wartości, jak ład, dobro czy harmonia, rozumiana także w sensie moralnym. Wreszcie, powtórzmy to po raz kolejny, kluczowego, jak się wydaje, paradygmatu dla wszelkich niemal wypowiedzi o charakterze modlitewnym dostarcza czarnoleskiemu poecie Księga Psalmów, postrzegana - co po wielekroć już pokazano - w kategoriach uniwersalnego, wykraczającego poza wąski horyzont wyznaniowych kontrowersji, modelu rozmowy człowieka z Bogiem ${ }^{30}$. Absolutnie dominującego wpływu psalmów na wrażliwość religijną Kochanowskiego z powodzeniem dowiódł już Fallek, nam pozostaje jedynie jego ustalenia z całą mocą potwierdzić.

Rzadko kiedy autor Satyra decyduje się porzucić wyznaczony przez tradycję Starego Testamentu (prócz Dawidowej psalmodii zwróćmy również uwagę na pisma proroków czy Księgę Hioba) leksykalno-wyobrażeniowy horyzont, a jeśli tak się dzieje, Kochanowski czyni to zwykle z bardzo konkretnych, wynikających z danej sytuacji komunikacyjnej, powodów. Zauważmy, że w przypadku takich choćby Wróżek określone odwołania ewangeliczne - do Jezusa, Piłata tudzież Barabasza - warunkowane są zapleczem retorycznym typowego przedstawiciela ówczesnego kleru i jawnie służą, realizowanej przez świadomego go autora, literackiej kreacji bohatera. Inna z kolei grupa odnotowanych tu przez nas przypadków to przykłady podjęcia bezpośredniej polemiki z reprezentantami stanu duchownego, czyniącej wręcz koniecznymi odpowiednio zaaplikowane argumenty wzięte z kart Nowego Testamentu. Tym tłumaczyć należy i zaangażowanie w antywojenną elegię Osm.,

\footnotetext{
${ }^{29}$ Za sugestię w tej sprawie chciałem podziękować prof. dr. hab. Krzysztofowi Obremskiemu.

${ }^{30}$ Sante Graciotti pisze: „Styl psalmów stał się częścią osobistego stylu poety” (Graciotii 1989: 337).
} 
I 10 postaci św. Piotra Apostoła i przedłożoną Lippomanowi przestrogę z fraszki $\mathrm{Na}$ posta papieskiego (I 50), w której padają słowa o „płaczu i tesknicy”. Inna sprawa, że prócz zabiegu czysto retorycznego, mającego na celu określony perswazyjny skutek, dałoby się pewnie dopatrzeć we wspomnianych tu utworach także innowierczej $\mathrm{z}$ ducha praktyki posługiwania się w polemice najbardziej autorytatywnym dla wyznawców protestantyzmu tekstem, jakim jest Pismo Święte.

Nie da się zatem w sposób mechaniczny przenieść poczynionych przez nas obserwacji na grunt dyskusji o wyznaniowych preferencjach Jana z Czarnolasu czy przy ich użyciu udzielić jakichś wiążących odpowiedzi na nurtujące badaczy w tym względzie pytania. Warto jednak na pewno przywrócić w tak zdefiniowanym sporze należne znaczenie dwóm, w naszym odczuciu, niezwykle antypapiesko ukierunkowanym tekstom Mistrza Jana, którym nie bez powodu zresztą zdecydowaliśmy się poświęcić nieco więcej uwagi. Rzecz dotyczy właśnie wspomnianej, adresowanej Pawłowi IV elegii Osm., I 10 oraz, powiązanej z nią, fraszki I 50. Tak kaliber stawianych tam zarzutów, jak i żarliwość, która ich formułowaniu towarzyszy, każą, naszym zdaniem, domniemywać, jeśli nie trwałych, to przynajmniej sytuacyjnie motywowanych (mowa tu o latach 1556 i 1557) innowierczych sympatii Kochanowskiego.

\section{BIBLIOGRAFIA}

Brückner Aleksander. 1924. Wstęp. Do: Jan Kochanowski. Pisma zbiorowe. Wyd. Aleksander Brückner. T. I. Warszawa: Instytut Wydawniczy „Bibljoteka Polska”. S. 1-86.

Chłędowski Kazimierz. 1959. Historie neapolitańskie. Warszawa: PIW.

Dąbkowska-Kujko Justyna. 2015. Jana Kochanowskiego refleksja o wojnie. W: Wiazanie Sobótkowe. Studia o Janie Kochanowskim. Red. Estera Lasocińska, Wiesław Pawlak. Warszawa: IBL PAN. ISBN: 978-83-6175-771-9. S. 238-253.

Dopierała Kazimierz. 2019. Księga papieży. Poznań: Zysk i S-ka Wydawnictwo. ISBN: 978-83-8116-793-2.

Fallek Wilhelm. 1931. Świat biblijny w twórczości Kochanowskiego. W: Pamiętnik zjazdu naukowego im. Jana Kochanowskiego w Krakowie 8 i 9 czerwca 1930. Kraków: Polska Akademia Umiejętności. S. 383-421.

Graciotti Sante. 1989. Religijnośc poezji Jana Kochanowskiego. W: Jan Kochanowski 1584-1984. Epoka - twórczość - recepcja. Red. Janusz Pelc, Paulina Buchwald-Pelcowa, Barbara Otwinowska. T. I. Lublin: Wydawnictwo Lubelskie. S. 331-347.

Horacjusz Flakkus Kwintus. 1986. Dzieła wszystkie. T. I: Ody i epody. Tekst łaciński do druku przygotował, wyboru przekładów dokonał, przedmową, życiorysem poety, wersyfikacją i komentarzem opatrzył Oktawiusz Jurewicz. Wrocław: Ossolineum. ISBN: 83-0401885-3. 
Ioannes Cochanovius: pisma tacińskie. 2008. Oprac. zespół pod kierunkiem Wacława Waleckiego. Kraków: Collegium Columbinum. ISBN: 1895-6076.

Kochanowski Jan. 1962. Odprawa postów greckich. Oprac. Tadeusz Ulewicz. Wydanie X, zupełnie zmienione. Wrocław-Warszawa-Kraków: Ossolineum.

Kochanowski Jan. 1972. Treny. Oprac. Janusz Pelc. Wydanie XIII zmienione. Wrocław: Ossolineum.

Kochanowski Jan. 1980. Dzieta polskie. Oprac. Julian Krzyżanowski. Warszawa: PIW. ISBN: 83-06-00247-4.

Kochanowski Jan. 1983. Treny. Oprac. Maria Renata Mayenowa, Lucyna Woronczakowa oraz Jerzy Axer i Maria Cytowska. Wrocław: Ossolineum, Wydawnictwo PAN. ISBN: 8304-00671-5.

Kochanowski Jan. 1986. Z tacinska śpiewa Stowian Muza: elegie, foricenia, liryki. Przeł. Leopold Staff. Wstępem poprzedził Zygmunt Kubiak. Warszawa: PIW.

Kochanowski Jan. 1991a. Fraszki. Oprac. Janusz Pelc. Wydanie II zmienione. Wrocław: Ossolineum. ISBN: 83-04-03600-2.

Kochanowski Jan. 1991b. Pieśni. Oprac. Maria Renata Mayenowa, Krystyna Wilczewska, przy udziale Barbary Otwinowskiej oraz Marii Cytowskiej. Wrocław-Warszawa-Kraków: Ossolineum, Wydawnictwo PAN. ISBN: 83-04-02209-5.

Kochanowski Jan. 1997. Pieśni. Oprac. Ludwika Szczerbicka-Ślęk. Wydanie czwarte zmienione. Wrocław-Warszawa-Kraków: Ossolineum. ISBN:83-04-04398-X.

Kochanowski Jan. 2008a. Carmina latina / Poezja tacinska. Cz. I: Fototypia-transkrypcja. Wyd. i wstępem poprzedziła Zofia Głombiowska. Gdańsk: Wydawnictwo Uniwersytetu Gdańskiego. ISBN: 978-83-7326-562-2.

Kochanowski Jan. 2008b. Carmina latina / Poezja tacińska. Cz. II: Indeks form i wyrazów. Oprac. Zofia Głombiowska, przy współudziale Stefanii Głombiowskiej. Gdańsk: Wydawnictwo Uniwersytetu Gdańskiego. ISBN: 978-83-7326-563-9.

Mańkowski Jerzy, Skolimowska Anna. 1994. Polskie śpiewy o Męce Pańskiej - nieznana czastka twórczości Jana Kochanowskiego. „Odrodzenie i Reformacja w Polsce”, R. XXXVII. ISSN: 0029-8514. S. 95-98.

Noel Gerard. 2007. Występni papieże renesansu. Prawda czy czarna legenda? Przeł. Grażyna Waluga. Warszawa: Wydawnictwo Amber. ISBN: 978-83-2412-984-3.

Nowicka-Jeżowa Alina. 2015. Jan Kochanowski wobec protestantyzmu. W: Ewangelizm reformowany $w$ Pierwszej Rzeczypospolitej. Dialog z Europa $i$ wybory aksjologiczne $w$ świetle literatury i piśmiennictwa XVI-XVII wieku. Red. Dariusz Chemperek. Warszawa: Wydawnictwa Uniwersytetu Warszawskiego. ISBN: 978-83-2352-155-6. S. 216-274.

Pismo Święte Starego i Nowego Testamentu w przektadzie z języków oryginalnych. 1996. Oprac. zespół biblistów polskich z inicjatywy benedyktynów tynieckich. Poznań: Wydawnictwo Pallotinum. ISBN: 83-7014-218-4. 
Ranke von Leopold. 1981. Dzieje papiestwa w XVI-XIX wieku. Przeł. Jan Zarański, Zbigniew Żabicki, wstępem opatrzył Marian Henryk Serejski. T. 1. Warszawa: PIW. ISBN: 83-06-00591-0.

Rusnak Radosław. 2019. „Elegii ksiag czworo” Jana Kochanowskiego - w poszukiwaniu formuty zbioru. Warszawa: Wydział Polonistyki Uniwersytetu Warszawskiego. ISBN: 978-836566-791-5.

Stownik polszczyzny Jana Kochanowskiego. 1994-2012. Red. Marian Kucała. T. I-V. Kraków: Instytut Języka Polskiego PAN. ISBN: 83-8557-996-6.

Teusz Leszek. 2002. „Bolesna Muza nie Parnasu Góry, ale Golgoty...”. Mesjady polskie XVII stulecia. Warszawa: Wydawnictwo Semper. ISBN: 83-8910-015-0.

Urban-Godziek Grażyna. 2012. Elysium of Love Poets. The Beginnings of the Motif in the Classical Litterature. „Episteme. Czasopismo Naukowo-Kulturalne”, nr 17. ISSN: 18954421. S. 15-35.

Urban-Godziek Grażyna. 2014. Jana Kochanowskiego elizejski krag poetów samobójców i jego źródta literackie, czyli od eschatologii epickiej do elegijnej. W: Olimp-ideat, doskonatośc, absolut. Red. Maria Korytowska, Iwona Puchalska. Kraków: Wydawnictwo Uniwersytetu Jagiellońskiego. ISBN: 978-83-2333-757-7. S. 211-228.

Weintraub Wiktor. 1974. Religia Kochanowskiego a polska kultura renesansowa. „Pamiętnik Literacki”, t. 65. S. 3-22.

Wojtyska Henryk Damian. 1977. Papiestwo - Polska 1548-1563: dyplomacja. Lublin: Towarzystwo Naukowe KUL.

Radostaw Rusnak

\title{
A NON-EXISTENT NEW TESTAMENT. ON THE CONFESSIONAL ASPECTS OF JAN KOCHANOWSKI'S RELIGIOUS POETRY
}

\author{
(abstract)
}

The article lists all references to the New Testament characters, like Jesus Christ, Saint Peter, and Lazarus, in Jan Kochanowski's works. To some of them additional commentaries are given, e.g. to Elegy I 10 (from the collection Elegiarum libri duo) where the scene of the betrayal of Judas is used as a warning to the bellicose pope Paul IV who intended to regain Naples. The article also points to the fragments where the presence of Christ may be seen as desirable or even necessary and yet he is conspicuous by his absence. This particularly applies to Laments, as the collection completely ignores the Christian perspective on the redemptive power of suffering. Given the scarcity of references to the New Testament in 
Jan Kochanowski's works, which is even more striking when compared to the multiple references that they make to David's psalms, the article speculates on the reasons for Kochanowski's preferences as well as opens a broader discussion on the confessional aspects of Kochanowski's poetry.

\section{KEYWORDS}

Jan Kochanowski; religious poetry; the New Testament; Laments; Polish Renaissance literature 